\title{
Limits to Regulating Irregular Migration in Turkey: What Constrains Public Policy and Why?
}

\section{Saime Ozcurumez \& Denız Yetkın}

To cite this article: Saime Ozcurumez \& Denız Yetkın (2014) Limits to Regulating Irregular Migration in Turkey: What Constrains Public Policy and Why?, Turkish Studies, 15:3, 442-457, DOI: 10.1080/14683849.2014.954746

To link to this article: http://dx.doi.org/10.1080/14683849.2014.954746

$$
\text { 曲 Published online: } 05 \text { Sep } 2014 .
$$

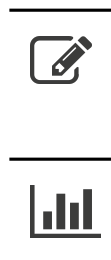

Submit your article to this journal ¿

M Article views: 372

Q View related articles $₫$

View Crossmark data $\nearrow$

4 Citing articles: 1 View citing articles 


\title{
Limits to Regulating Irregular Migration in Turkey: What Constrains Public Policy and Why?
}

\author{
SAİME OZCURUMEZ \& DENIZ YETKIN \\ Department of Political Science and Public Administration, Bilkent University, Ankara, Turkey
}

\begin{abstract}
Turkey, similar to its counterparts in emerging markets, has been aiming to reduce irregular migration effectively and comprehensively with various sets of policies since the 1990s. However, the number of undocumented migrants continues to increase and unregistered foreign employment is as high as ever. This study aims to explain the reasons underlying this conundrum by focusing on the nature of the policies adopted and the characteristics of the target population relying on data collected on a sample of unregistered foreign workers in the textile sector in Istanbul. It argues that the reasons for the limited effectiveness of the policies is attributable to structural factors such as inherent problems with the existing policies for regulating irregular migration and preferences as well as the behavior of the unregistered foreign workers and their employers.
\end{abstract}

\section{Introduction}

Modern states have always aimed to control movement across and within their borders since the marking of territorial sovereignty. These efforts, however, have never gone unchallenged. One recent test stems from irregular, undocumented and illegal mobility, which has increased in proportion to pull factors in emerging markets and push factors in developing countries. States invariably tackle this challenge with a standard policy toolkit consisting of stricter regulations on border control and criminalization of unregistered employment of foreigners as well as amnesties for providing regularization opportunities. Notwithstanding these efforts, the reality of unregistered foreign employment and irregular migration persists. This study addresses this conundrum-the conspicuous mismatch between policy objectives and outcomes in the area of irregular migration-relying on a case study on unregistered foreigners who are employed in the textile sector in Istanbul, Turkey. This paper concludes that in combating irregular migration, the universal policy toolkit falls short of achieving its objectives for two reasons. First, this one-size-fits-all toolkit is composed of a generic set of

Correspondence Address: Saime Ozcurumez, Department of Political Science and Public Administration, Bilkent University, Ankara, Turkey. Email: saime@bilkent.edu.tr 
instruments, which do not indiscriminately address particular needs of a given state. Second, these policies are implemented without having identified the root causes of irregular migration, i.e. inexorable structural factors as well as acute needs of migrants, both of which render this type of mobility interminable.

The argument is presented by, first, demonstrating how the existing literature on irregular migration is focused exclusively on immigration control and regularization efforts in the form of sanctions and amnesties. By doing so, the literature largely overlooks the choices and behavior of irregular migrants themselves, which are, we observe, beyond states' control and results in the overestimation of the effectiveness of such measures on the ground. In order to overcome this neglect, this research complements the findings of the policy measures literature with those of studies on the characteristics of the target population and contends that only through a synthesis as such can we explain the striking gap between policy objectives and outcomes. Second, the legislation on irregular migration and unregistered employment in Turkey is reviewed so as to show how the policy measures are paralleled to those universally adopted in other states. The paper emphasizes how such emulation results in the gap between policy objectives and outcomes in Turkey as well. Third, the paper presents data from interviews carried out with unregistered foreign workers and identifies the root causes of persistent irregular migration that the existing policy measures cannot address. Finally, it concludes with a discussion of research findings that warrants an ex ante policy impact assessment taking into account both the specific characteristics of the target population and the observed results of policy measures implemented in other states.

\section{Studying Irregular Migration: From Immigration Control and Regularization to Migrants' Preferences and Behavior}

This section reviews the studies on international mobility and irregular migration, which focuses on immigration control and regularization policies and amnesties. The section will show how the existing general literature suffers from the pitfalls of state-centralism, as it largely overlooks the choices and behavior of irregular migrants themselves. The literature on Turkey, too, parallels the state-centered focus in the general literature. The section concludes by calling for combining these analyses of state policies on immigration control and regularization with others focusing on the characteristics of the target population. Only through such synthesis the study explains the mismatch between policy objectives and outcomes in the area of irregular migration.

The early literature on international migration emphasizes states' ability to control cross-border mobility. This early wave, dominated by neoclassical economists, explained international migration through macro- and micro-level dynamics. Those who focus on macro-level variables explained international mobility by focusing on labor migration in the process of economic development. According to this perspective, governments are able to control migration by regulating labor markets in the receiving and sending countries. ${ }^{1}$ Others who focused on micro-level dynamics, 
however, emphasized the role of immigrants' agency. These scholars claimed that rational individuals migrate in order to increase their earnings. According to this literature, governments could control international migration with the help of incentive structures, i.e. specific policies that affect expected gains in the sending and/or receiving countries-for example, through policies lowering the likelihood of employment or raising the risk of underemployment in the destination country (by introducing sanctions on employers), through programs that raise income levels in the country of origin (such as long-term development programs), or through strategies that increase the costs (both psychological and material) of migration. ${ }^{2}$ A later wave in the literature stemming from what is termed as the 'new economics of migration', too, saw states as able to steer migrants' immigration decisions, and hence irregular migration itself, through policy levers creating incentives, and more significantly disincentives, for mobility in labor markets, insurance markets, capital markets and futures markets. ${ }^{3}$

Based on the common perception that states were actually able to control migration, another body of literature focused on regularization policies and amnesties. This literature documented episodes in different states on the introduction of amnesties for irregular migrants during the past three decades (e.g. Argentina in 1994, Belgium in 2004, the USA in 1986 and Greece in 1997-1998 and 2001). However, a skeptical line emerged within this literature whereby various studies pointed to limits of states' control over irregular international mobility as evidenced by elusive results achieved by regularization measures and amnesties. One authoritative empirical study on the 1986 Immigration Reform and Control Act introducing an amnesty in the USA, for example, concluded that while this law resulted in lower levels of cross-border interceptions for a period in the short run, irregular migration increased thereafter only to return to former levels several years later. ${ }^{4}$ Despite the negative findings of these studies, it is striking that introducing amnesties continue to remain as a common policy measure. ${ }^{5}$ While there emerged no consensus among policy-makers and the public on whether amnesties actually curb illegal migration, very few studies attempted to explain why these regularization measures and amnesties do not deliver on their promise. ${ }^{6}$ This lacuna stems from the fact that the existing general literature suffers from the pitfalls of state-centralism in that studies focusing on immigration control and regularization measures largely overlook the choices and behavior of irregular migrants themselves, which may potentially explain why individuals with irregular status continue to take the risk of staying in the destination country. ${ }^{7}$ In this way, the literature categorically overlooks the possibility that irregular migrants may actually prefer to remain irregular/unregistered. Such choice by migrants negates the rationale for the oft-resorted regularization policies altogether. This study aims to overcome this gap by examining how irregular migrants' preferences and behavior sustain irregularity in an environment where states continue to hold onto control practices, regularization measures and amnesties.

In parallel to the general literature on international mobility, there emerged studies on Southern European states in general, and Turkey in particular, as they are situated on Europe's most tested borders. In the case of research on Turkey, the literature, too, focuses on immigration control without addressing why irregular migrants actually 
prefer to remain so. This state-centered literature concentrated on the rules, regulations and policies on irregular migration ${ }^{8}$ in a policy context of deepening Europeanization. ${ }^{9}$ Other studies, which focused on irregular migrants themselves, described how human trafficking and smuggling takes place through Turkey, ${ }^{10}$ how migrants survive in general ${ }^{11}$ and how they operate in the labor market ${ }^{12}$ in particular. Therefore all of these studies cited above exclusively focused on state control from a politico-legal perspective, and when they did study migrants, they did so only to describe the livelihoods of migrants from a sociological perspective. Paralleling the gap in the international literature on irregular migration, therefore, works on Turkey did not aim at empirically studying migrants' preferences and behavior within the constraints set by states. Such lacuna in this literature, too, precluded an analysis that would explain the reasons behind the mismatch between policy objectives and outcomes.

\section{The Added Value of Studying the Case of Unregistered Foreign Employment in the Textile Sector}

In order to bridge this gap not only in the scholarly literature but also on policy objectives and outcomes, this study examines both state efforts and migrant views through interviews with irregular migrants and their employers in the textile sector in Istanbul, as well as interviews with policy-makers, employers and trade unions. The textile sector constitutes a crucial case in understanding the reasons for unregistered foreign employment and why regularization policies remain constrained in their outcomes. ${ }^{13}$ Although reliable data do not exist as to the magnitude of informality in the workforce and it is difficult to estimate the share of foreign workers in this sector, textiles is often referred by experts in the field to as one of the most competitive sectors in the Turkish economy which thrives on informal employment. Moreover, official sources confirm that this sector is also one where undocumented foreign workers are highly concentrated along with tourism. ${ }^{14}$ Istanbul, followed by Bursa and Eskişehir, is the major hub of the textile industry ${ }^{15}$ and these constitute areas of major concentration of unregistered foreign workers. These patterns are confirmed by the largest labor union in the textile sector, Textile Knitting and Clothing Industry Workers' Union (Türkiye Tekstil, Örme ve Giyim Sanayi İsçileri Sendikası, TEKSİF), which declared that over 80 percent of the workforce in the sector remain unregistered and that this sector employs a bulk of unregistered foreign workers. ${ }^{16}$ By bringing original research on the textile sector in Turkey and unregistered foreign employment therein, this study advances the state-of-the-art of research on irregular migration. It does so by shedding new empirical light on migrants' preferences and behavior that would complement the existing research on state control focusing on legal and administrative changes. The next section provides an overview of these changes.

\section{Aligning With The Lawful Alla Turca}

Since the 1990s, Turkey has increasingly attracted regular and irregular international migration from mainly Russia, the New Independent States, Central and Eastern 
Europe, who arrived as petty traders, tourists and domestic workers. ${ }^{17}$ In the past two decades, many irregular migrants from countries such as Afghanistan and Iraq transited through Turkey. ${ }^{18}$ Although there are no reliable statistics reported on how many of the foreigners entering Turkey become undocumented workers, our interviews suggest that a significant percentage of those who enter as tourists do become "temporary residents and/or 'de facto' immigrants." 19 According to the interview data, a group of the temporary residents engage in unregistered work as sales representatives in the textile sector in Istanbul particularly if they come from countries with which these small shops trade mainly due to their language skills. ${ }^{20}$ These individuals continue to remain in Turkey by renewing their tourist visas or prefer staying with expired visas. $^{21}$ Increasing number of demands for entry and stay in Turkey has been regulated by a plethora of legislation dispersed across the jurisdiction of various ministries, which arguably has also resulted in widening the gap between the policy objective and outcome in the last few decades.

Until the 2013 Law on Foreigners and International Protection (LFIP), matters concerning the entry, stay and exit of foreigners in Turkey were governed by the Law on Residence and Travel of Foreigners in Turkey (Law No. 5683, adopted in 1950), the Passport Law (Law No. 5682, adopted in 1950) and the Law on Work Permits for Foreigners (LWPF, Law No. 4817, adopted in 2003). Since the 1950s, there have been 13 addendums and 8 amendments to these existing laws; however, none of these amendments directly addressed the issue of irregular migration. A provision on the rights of foreigners had been added to the 1961 Constitution, however, who had been identified as "the foreigner" had not been defined by law at the time. ${ }^{22}$ Law No. 4817, LWPF, adopted in 2003, defined "a foreigner" as the one who is not a Turkish Citizen according to Turkish Citizenship Law No. 403. ${ }^{23}$ This law also constituted one of the first formal attempts at introducing and implementing a single legislation for effective prevention against unregistered foreign employment. ${ }^{24}$ In addition to initiatives on amendments to laws and regulations governing the entry and stay of foreigners, Turkish policy-makers focused on information dissemination, awareness raising campaigns and training of employers to encourage legal employment of foreigners through mainly the Action Plan to Fight against Informal Labor during the 2000 s. $^{25}$

In 2003, Turkish Citizenship Law, Law No. 403, was amended introducing strict measures and requirements such as the obligation to wait for three years before starting the naturalization procedures of foreigners married to Turkish citizens with the objective of preventing "fake marriages" which were considered as facilitating irregular migration (especially of women), human smuggling and trafficking, and also unregistered foreign employment. ${ }^{26}$ In 2004, Road Transportation Law came into force stipulating penalties against human smuggling; and in 2005, Article 79 of the new Turkish Penal Code (Law No: 5237) introduced heavy sanctions to migrant smugglers. $^{27}$

The policy outcomes of all the policy initiatives of the 2000s cited above, to fight irregular migration, constituting of sanctions to violators of visa laws and those who abuse the system, remain elusive. According to official statistics and EU Progress 
Reports of the 2000s, unregistered foreign employment and the number of irregular immigrants continued to increase in the late 1990s and 2000s. From 1995 to 2010, the number of foreigners coming to Turkey increased from 6,762,956 to 27,024,609, and 829,161 irregular migrants were apprehended in the same period. ${ }^{28}$ The share of the informal economy also increased in the same period from around 25 percent to over 31 percent. $^{29}$ In the early part of the 2000 s, the informal economy was estimated to account for 50 percent of the total economy. ${ }^{30}$

The reported statistics on the combat against irregular migration in the latter parts of the 2000s fluctuate. The numbers of apprehended irregular migrants gradually decreased from 65,737 in 2008 to 34,345 in 2009 and 32,667 in 2010, and increased to 44,415 in 2011 as cited in EU Progress Reports. Although these fluctuations validate the claim that sanctions or amnesties are highly unlikely to drastically change patterns of irregular migration or the unregistered employment of foreigners in the longer term, policy-makers cite the sanctions as relatively successful in decreasing irregular migration and unregistered foreign employment. They characterize these fluctuations as a sign of policy success. An amendment to Law No. 5683 (Law on Residence and Travel of Foreigners in Turkey) on October 10, 2011 stipulated that foreigners will be able to renew their visa in the country if they have not overstayed the 90-day limit, and they may be issued a six-month residence permit. ${ }^{31}$ Our interviews suggest that policy-makers have identified this amendment as highly effective in reducing the levels of unregistered unemployment of foreigners, and increasing applications for work and residence permits by foreigners. Our interview data suggest that applications for residence permits jumped twofold from more than 35,000 to nearly 80,000 from 2011 to 2012, and work permits granted increased from close to 30,000 to 42,000 in the same period. However, there are no clear grounds for suggesting that this jump in the positive direction is attributable to the amendment. It is highly likely that such change is a consequence of both the sanctions and the easing of visa issuance.

On June 7, 2012, the Ministry of Interior issued an amnesty, according to which all foreigners in Turkey without a visa or residence permit (regardless of the duration of the visa violation, the residence fees and penalties resulting from violations of up to six months) could apply for a residence permit. ${ }^{32}$ The objective of this amnesty, similar to the previous domestic initiatives, was to reduce the number of irregular immigrants and prevent unregistered employment by allowing foreigners (who were in irregular status) to legalize their status in Turkey for another six months by paying only the fees for the permits and not the fines for the violation of the permits. This amnesty also imposed a time limit: only foreigners who violated their residence permit before May 28, 2012 would be eligible and they would need to pay their fees by August $15 .{ }^{33}$ The policy impact of this amnesty also remains elusive, as there are no reported statistics, which note a significant increase on valid work permits or a substantial decrease in irregular migration.

One of the main objectives of the LFIP, which is the most comprehensive attempt to centralize the legislation on migration and asylum to date in Turkey, is to enhance the institutional capacity of Turkey on immigration and international protection. The 
principles and procedures concerning the entry to, residence in and exit from Turkey, the scope and the implementation of the protection to be provided for foreigners who request protection, as well as the establishment, duties and authorities of the Directorate General of Migration Management at the Ministry of Interior are regulated with this new law. Article 12 of the LWPF (Law. No. 4817) has also been amended recently, and according to this amendment foreigners shall make their first work permit applications directly to the Turkish Consulates in their countries of origin. Therefore, by applying for a work permit for longer periods of time, foreigners will be able to legally reside and work in Turkey for extended periods of time hence preventing becoming a visa-overstayer. Article 3 of the Social Insurance and General Health Insurance, Law No. 5510, has also been amended. While the law only covered stateless persons and refugees in the past, it currently covers foreigners who have filed applications for international protection or the status of a stateless person and a refugee. ${ }^{34}$ Therefore, foreigners have been introduced with another incentive for regularizing their status in order to enjoy health and social insurance benefits as a result of their legal employment in Turkey.

The beginning of accession negotiations with the EU in October 2005 constituted a turning point in the changes in immigration and asylum law in Turkey. The need for a new policy on immigration has been repeatedly highlighted as urgent by policy-makers and scholars, and emphasized in different Progress Reports. ${ }^{35}$ The commitment to harmonization of Turkish legislation on immigration and asylum with that of the EU throughout the EU accession process has been clearly expressed in the National Action Plan in $2005 .{ }^{36}$ However, whether the EU constitutes the only and most significant impact in the policy changes in the 2000s is questionable. Turkey was recognized as a country of immigration beginning with the late $1990 \mathrm{~s}^{37}$ and the policy initiatives, amendments to different laws and regulations on foreigners can also be traced back to the early 2000s as discussed earlier. Therefore, both domestic initiatives identified after the recognition of Turkey as an immigration country and the EU accession process have been instrumental in the introduction of new laws for governing migration in general and irregular migration in particular.

While modeled on various practices in other countries for combatting irregular migration and accelerated by the EU accession process, whether such amendments are likely to reduce unregistered employment and irregular migration remains elusive. This study shows the main reason for such precarious results is that countries emulate amnesties as the most readily available and convenient tool for regularization without necessarily focusing on an impact analysis in other countries. Therefore, most of the amendments remain fairly limited in combatting unregistered employment in different sectors contributing to the discrepancy between the policy objective and outcome. The next section covers data from interviews with a group of unregistered textile sector workers and their employers. We aim to shed light on the reasons, which are not covered by the regulations and laws introduced until the April 2013 law, and discuss the limits of policies on irregular migration. 


\section{From Irregular to Regular Status? Why and Why not?}

This section explores the socioeconomic backgrounds, working conditions, job seeking strategies and decision-making patterns of irregular migrants. This section presents an analysis of their interactions with Turkish society, relations with their employers, state institutions and networks within Turkey. The accounts of the target population, policy-makers, employers and trade unions are highly likely to shed light on why policies on unregistered foreign workers and irregular migration are ineffective.

\section{Remaining Unregistered as Choice?}

Data from our interviews with policy-makers suggest that amendments in regulations and amnesties aim to control the informal labor market of foreigners while improving their working conditions in Turkey. However, the account of undocumented migrants suggests that they remain undocumented despite the amnesties because they aim to avoid the cost of regularization altogether. A Turcoman male interviewee (URFW. 4$)^{38}$ notes, "I do not receive any visa. I do not go to my country for obtaining a visa. This process is very expensive. You should give up all you have earned for this entry and exit process." Moreover, while undocumented, these individuals lack access to basic services in the workplace health and safety in particular and health-care services in general. A Ukrainian female interviewee (URFW.1) reports, "We do not have the right to work here, that is why it is hard ... I do not have health insurance. I do not know any institution about immigrants. For the health issue, I am self-funded." Moreover, they remain a vulnerable group overall vis-à-vis any assault or discrimination, which remains unreported due to fear of deportation. A female Moldovan interviewee (URFW.18) notes, "I do not feel safe in Turkey. Two years before, I tried to defend myself from someone who attacked me with a knife. Because of my visa problems, I could not contact the police."

The unregistered foreign employees converge on a demand to improve working conditions. However, a major challenge is lack of awareness of any institutions and/or initiatives concerning migrants among the migrants themselves. Therefore, there is a significant lack of congruence between the objectives of the legislation and initiatives pursued by the Ministry of Labor and Social Security (MoLSS), and awareness of the implications among the target population. Our interview data suggest that the LWPF (Law no. 4817) and the amendments did not reach its target group in letter or spirit when it was amended. A Ukrainian female interviewee (URFW.1), similar to many others, reports, "I talk with my friends from Ukraine, and learn issues about immigrants. I do not know any institutions [in Turkey] about [for] us." These migrants therefore exist in isolation from the society and institutions and uninformed about their social, political and economic rights in Turkey while they operate at the center of labor market exchange for some sectors such as the textile industry. 
The analysis reveals that the interviewees view the visa application process as complicated and far from welcoming similar to their concerns with the regularization process, which contributes to the mismatch between policy objectives and what the policy delivers. A female Bulgarian interviewee (URFW. 2) reports:

Before the application to Residence Permit, I lived here [in Istanbul] for three months; then go back to Bulgaria and live there for three months. Then, I made an application in Istanbul that was rejected. I applied in Ankara; they accepted and gave me a temporary residence permit. Later, when I went to pay for my Residence Permit in Istanbul, they said that I had to pay a fine since I am illegal immigrant. Although I said that I had a temporary residence permit, they did not accept [it]....

Unregistered employment and irregular migration mutually reinforce each other in Turkey as well. Irregular immigrants cannot be registered if they work due to their illegal stay in the country; hence they continue to work informally. Once they work unregistered, they cannot address the security forces or the MoLSS for the violations of their rights as human beings and/or employees because then they would be reporting on their immigration status and risking fines and/or expulsion. A major challenge in this complicated web of relationships is the proliferation of incidents of maltreatment and harassment in the work place. A male Turcoman interviewee (URFW. 3) reports:

Our employer took our passports. In the first week of our job, one of our good friends found a better job for us. We said to our employer 'Do not give us our weekly wages give our passports and let us go.' However, he did not give them .... He said that we could go to police...

Moreover, safety in the workplace and the exploitation by the employment agencies (which usually seize wages for the first few months of employment as service fee) constitute common challenges for all unregistered foreign workers. Various interviewees note that they have not been allowed lunch breaks, coffee breaks and were forced to work all days of the week as well as the weekends, day and night, without any overtime pay. While being subject to inhumane treatment, several of the unregistered foreigners are still willing to continue to work due to dire conditions in their countries of origin.

\section{Remaining Unregistered by Force?}

The most cited premise in the literature on irregular migration is that the nature of the liberal market economy perpetuates the informal economy and the employment of unregistered foreigners ${ }^{39}$ hence, the increase in unregistered employment is usually inevitable. In this study such reasoning is not necessarily inevitable except when policies for monitoring and combatting irregular migration do not match the local needs, 
both of the target population and the receiving state. The data from the interviews indicate that both irregular migrants and their employers express their concern over the illegality of their situation and its potentially dire consequences for both parties. However, they both note that they lack major incentives to rearrange their conditions toward establishing a legal work contract. One of the employers states that while authorities remained aware of how they employed foreigners, the infrequency of inspections lead them to continue with employing unregistered foreigners. Both employees and employers also note that their informal interaction with some of the law enforcement actors also help them prolong illegality viewed as less costly than legalization by both parties.

While these individuals are employed in the informal economy, they also become entangled in a web of irregularities in their processes of settlement, integration and the services they receive for education (mostly of dependents such as spouses and children), housing and the health-care sector. Different employers highlight that children of undocumented migrants attend school with irregular status, which jeopardizes the continuity of their education. These individuals are also unable to rent decent houses as landlords are not able to prepare leases with properly arranged legal rights and responsibilities for the tenants. Moreover, receiving health-care services for irregular migrants becomes more costly as according to the interview data most hospitals ask for extra charges in order not to report the status of the patients to law enforcement officers. While the legislation might provide comprehensive measures to govern unregistered employment with repeated amendments to existing legislation as discussed in the section on policies, the incentives for acting within the requirements of the legislation are neither widely communicated nor promoted among irregular migrants and their employers.

The demand for cheap immigrant labor in the growing Turkish economy sustains unregistered employment the most, hence in the short run rendering such demand by employers unremitting. According to policy-makers at the MoLSS, they have made repeated efforts to "formalize unregistered workers by offering incentives to clear the preceding fines for the employers." However, the policy-makers note that the employers insist on employing unregistered foreign workers also in order to evade taxes. The policy-makers dub this as "an attitude of evading taxation," "avoiding insurance premiums" and "stealing from the state" in an otherwise lucrative employment contract. Moreover, the employers highlight the textile sector as requiring dexterity, and note that the foreign workers are usually highly skilled labor who would agree to low-paid jobs in this sector. For example, interview data suggest that employers prefer to hire "a Russian-speaking packaging assistant who may also serve as a sales representative" as unregistered, to employing a Turkish person who would only perform the job s/he has been hired for. Interviews with unregistered foreign workers confirm this attitude by employers as Russian-speaking women serve as "models, sales representatives and cleaning ladies." Therefore, the employers emphasize their preferences to employ unregistered highly skilled foreign workers to increase the quality of the product output at lower costs. Consequently, irregular migrants are caught in a spiral of maltreatment and harassment due to their illegality 
and informality breeding continuous invisibility. The individuals who have taken the risk of moving to another country for better job prospects and better pay are not able to take another step/risk to pursue their rights as foreign workers. They become participants in the informal economy more than stakeholders for demanding improved working conditions due to their irregular status.

One other factor that contributes to the mismatch between the policy objective and outcome rests in these individuals' preference to remain irregular, despite the risks involved. Turkey has adopted visa exemptions for touristic travel up to 90 days for ordinary passport holders for nationals of several countries, which are also main sources of unregistered foreign workers in Turkey. Interview data suggest that once these individuals enter Turkey with a tourist visa allowing entry and stay for up to 90 days, many engage in unregistered employment activity during the period when their tourist visas (which do not allow employment) remain valid. Should they prefer to continue unregistered employment, the common practice is to return to country of origin, obtain a new tourist visa and return to Turkey for another spell of unregistered employment activity. ${ }^{40}$ That is, they are legally permitted in Turkey under a tourist visa, but then participate in unregistered employment that is not permitted under a tourist visa. Therefore, while visa liberalization policies aim to increase the volume of trade with certain countries, they have an unintended consequence of promoting unregistered employment in Turkey. While there are no detailed studies documenting the severity of the adverse effects of these policies on each other, our interview data suggest that a fair number of tourists in need of employment are highly likely to take the risk of unregistered employment due to high rates of unemployment in their countries of origin. Many of the interviewees note that the cost of living with the fear of expulsion is less than the cost of being regularized through obtaining valid visas and work permits. ${ }^{41}$ Nevertheless, there are other reasons for the existing unregistered foreign labor and irregular migration. For instance, employers' attitudes and preferences concerning the employment of foreigners in the informal economy impact the state's ability to control international and irregular migration. Therefore, the choice made by employers for employing foreigners is not only about hiring cheap labor but also about having more qualified workers (compared to the natives who would be interested in applying for the same kind of job) who usually perform various tasks for less pay than native workers.

The income levels of migrants employed in the informal sectors are considerably lower than those of the natives while still constituting substantially higher earnings when compared to potential income in the country of origin for a similar job, or even a highly skilled job. Our interview data also suggest that the employment conditions of Turkish companies operating in the countries of origin of the foreigners in the informal sector in Turkey serve as a pull factor for these individuals to arrive in Turkey for employment. Employers also underline the attractiveness of the higher wages, and that foreign workers receive almost four times (30-40 USD in their country of origin as opposed to 120-130 USD in Turkey per month) more than what they would receive in their country of origin for their labor though still less than what a native worker in Turkey would receive for a similar task. While 
policy-makers are fully aware of the discrepancy in income levels and working conditions of the unregistered foreign workers, the policy initiatives become ineffective due to the mere scale of the demand for cost-effective employment strategies in the textile sector.

\section{Conclusion}

As an emerging market and a relatively successful survivor of the 2008 economic crisis, Turkey is increasingly more attractive for non-Turkish nationals who suffer from high rates of unemployment in their countries of origin. Some of this employment arrives legally and documented while a large portion arrives irregularly and stays as undocumented while integrated to the informal labor market, which constitutes close to half of the economy. While aiming to promote registered employment of and combat unregistered work by foreign nationals, Turkey adopts various policies and legislation with regulations seemingly easing acquisition of residence and work permits. However, the policies are generally mere replicas of practices adopted by other countries, which face irregular migration, and often provide mixed results. In the case of Turkey, these mixed results are further complicated by how the policy is received as well as the characteristics of undocumented migration. Evidence in this research does not suggest that regularization measures such as amnesties are inherently flawed in themselves. However, it indicates that amnesties address only part of the problem of irregular migration. This study demonstrates that they may even perpetuate the problem of irregular migration by implanting an expectation of the announcement of another amnesty at another time among the irregular migrants.

On the policy side, the different regulations usually have their own limits. Until the April 2013, LFIP, legislation has been dispersed and remained open to administrative discretion. The amnesties and various regularization facilitation attempts had been restricted by time limitations, fines had been considered high and procedures far too complicated. After 2010, electronic applications became common in the issuing of work permits and following the processes of residence permits. However, end users note the difficulties of using the system and consultancy firms intervene to facilitate the implementation of the policy costing both the foreign workers and their employers' additional funds.

When analyzed from the point of unregistered foreigners, largely their preferences have been to remain unregistered, not because they aim to engage in illegal acts but because remaining unregistered is viewed as less costly by most. Although most prefer to receive equal pay for equal work, they prefer to be employed as undocumented to not having any income while in Turkey. The interviews confirm the findings in the literature that irregular immigrants face serious challenges concerning the job search, employers' attitudes, challenges of middlemen extracting income, working conditions, problems in relation to the state practices, unfair treatment by state authorities, stereotyping in the case of female migrants, lack of support for health policy, visa problems, and finally problems about their social life (adaptation to the culture in Turkey, housing problems and public attitude suggesting discrimination). 
This study aimed to explain why policies for combatting irregular migration and unregistered employment have not worked in the case of Turkey similar to many other countries. In contrast to most of the literature, which, for instance, focuses on the shortcomings of the existing policies, this research examines all sides of the testing process of irregular migration (policy-makers, employers and foreign workers). This study identifies four main reasons as to why the existing policies do not stop irregular migration and unregistered employment of foreigners. First, the policies have not been sufficiently adapted to the needs of the local context. Most of the policies such as amnesties are short-term focused and produce precarious results as they have done in other countries. Second, there are inherent problems such as the dispersed nature of the legislation prior to the April 2013 LFIP, which left room for administrative discretion thereby rendering the policy objective of combatting irregular migration almost unattainable. Third, unregistered employment in Turkey is nurtured by both the attractiveness of the growing economy in Turkey and the preferences of foreign workers as well as employers for unregistered work. Therefore, the choice to remain unregistered, despite its dire consequences, is likely to render all policy initiatives inapplicable. Finally, there is an urgent need to conduct an impact analysis of the causes and consequences of irregular migration in Turkey in order to devise a comprehensive and context sensitive policy framework that will support the recent LFIP.

\section{Acknowledgement}

We would like to thank the anonymous reviewers for directing us to clarify whether the amendments were attributable to only EU accession requirements or the local needs.

\section{Notes}

1. Massey, et al. "Theories of International Migration," 431-66, 433.

2. Ibid., 434.

3. Ibid., 436.

4. Orrenius and Zavodny, "Do Amnesty Programs Encourage Illegal Immigration?," 1-20, 14.

5. For example, the USA is, at the time of writing (September 2013), working on an immigration reform bill opening the path to citizenship to undocumented migrants and the UK has recently debated during the summer of 2013 whether to introduce a one-off amnesty to illegal migrants.

6. Epstein and Weiss "The why, when, and how," 285-316, 287.

7. The small group of studies that $d o$ focus on migrants, however, emphasizes only the efforts on the part of those migrants to regularize their status through marriage to nationals of the receiving country and use of ethnic networks to remain in receiving countries. See Staring, "Scenes from a Fake Marriage," 224-41, 224-5.

8. See also among others Kirişçi "Managing Irregular Migration in Turkey"; Kaya, "Legal Aspects of Irregular Migration"; Çiçekli, "Yasadışı Göç,İnsan Kaçakçılığı ve," 43-57.

9. Özçürümez and Şenses, "Europeanization and Turkey," 233-48.

10. Some examples are: Erder and Kaşka, Irregular Migration and Trafficking in Women; İçduygu and Toktaş, "How do Smuggling and Trafficking Operate via Irregular Border Crossing in the Middle East?" 25-54. 
11. See, for instance, İçduygu, Irregular Migration in Turkey; Brewer and Yükseker, "A Survey on African Migrants."

12. Some examples are Parla, "Irregular Workers or Ethnic Kin?" 157-81; Gülçür and Illkkaracan, "The "Natasha' Experience," 421-41; İçduygu, "The Labor Dimensions of Irregular Migration"; Dedeoğlu, "Garment Ateliers and Women Workers in Istanbul," 663-74.

13. Although most studies on irregular migration in Turkey focus on the care sector (foreigners working as domestic workers and care givers), the textile sector accounts much more than the care sector in terms of overall share in economic activity. Kaşka, "The New International Migration and Migrant Women in Turkey"; and Etiler and Lordoğlu, "Göçmenlerin Sağlık Sorunları."

14. Turkish Ministry of Labor and Social Security (MoLSS). "Kayıtdışı İstihdam ve Yabancı," 38.

15. Turkish Ministry of Labor and Social Security (MoLSS). "Hazır Giyim Sektöründe Çalışan İşçilerin (Risk Grubu: Kadın İşçi)."

16. "Sektörün acil çözüm bekleyen sorunları", www.teksif.org.tr/sektorelBilgiler.do (accessed September 3, 2013).

17. Erdem, "Migrations from the "Global South' and the Informal Economy in Turkey" 87-120, 105-6.

18. Kirişçi, "Turkey: A Country of Transition," 91-7, 91.

19. Zeybekoğlu and Johansson, Migration and Labor in Europe, 162.

20. Arı, Türkiye'de Yabancı İşşiler, 67.

21. Yıldız, "Foreign Workers in Turkey," 207-27, 207.

22. Aybay and Kibar, Yabancılar Hukuku, 73.

23. Ibid.

24. BMMYK Türkiye and Türk İçişleri Bakanlığı, Iltica ve Göç Mevzuatı, 20.

25. MoLSS, "Kayıtdışı İstihdam ve Yabanc1," 87, 109, and 117.

26. BMMYK İltica ve Göç Mevzuatı, 22.

27. Republic of Turkey, Ministry of Foreign Affairs, "Turkey's Fight Against Illegal Migration."

28. Directorate General of Migration Management, "General Ground of the Law."

29. Erdem, "Migrations from the 'Global South' and the Informal Economy in Turkey," 104.

30. MoLSS, "Kayıtdışı İstihdam ve Yabancı," 13-14.

31. Official Newspaper (accessed June 8, 2013). http://www.resmigazete.gov.tr/eskiler/2011/10/ 20111024-9.htm.

32. Foreigners Department for Residence Permit (accessed September 3, 2012). http://yabancilar.iem.gov. tr/index.html.

33. "Yabancilara Af Çıktı" (accessed September 3, 2012). http://haber.gazetevatan.com/yabancilara-afcikti/457901/1/Haber\#.UHcHHLQa6Es.

34. Ekşi, Yabancllar ve Uluslararasl, 132-4.

35. İçduygu, "Türkiye'de Uluslararası Göçün Siyasal Arkaplanı,"” 32 and Özçürümez and Şenses, "Europeanization and Turkey," 244.

36. See National Action Plan of Turkey for the Adoption of EU Acquis in the Field of Asylum and Migration adopted on 25 March 2005 (accessed June 5, 2014). http://www.goc.gov.tr/files/files/ turkiye_ulusal_eylem_plani(1).pdf.

37. İçduygu, "Türkiye'de Uluslararası Göçün Siyasal Arkaplanı", 29.

38. 'URFW.' is used for irregular migrant interviewee and 'EMP.' is used for employer interviewee.

39. Erdem, "Migrations from the 'Global South' and the Informal Economy in Turkey," 104.

40. In order to prevent this route to unregistered employment, a policy measure was introduced on February 1,2012 according to which a foreigner who holds a tourist visa or border gate visa for three months should stay at least 90 days in his/her country before coming back to Turkey. http://www. yabancicalismaizni.com/hizmetler/yabanci-hizmetci-calistirmak.html. The effects of this change in the visa regime are simply too soon be evaluated.

41. For instance, the amount of fees required for work permit for a definite time period (2013) are 158.25 TL (58.6 Euro) up to one year and 476.30 TL (176.4 Euro) up to three years. http://www.csgb.gov.tr/ csgbPortal/yabancilar.portal?page=harc_banka (accessed August 29, 2013). 


\section{Notes on Contributors}

Saime Ozcurumez is Assistant Professor at the Department of Political Science and Public Administration at Bilkent University, Turkey. Her research interests are Comparative Politics, European Politics, Policy, Politics and Governance of the European Union, Immigration Law and Policy, Social Movements and Comparative Health Policy and Politics.

Deniz Yetkin is a $\mathrm{PhD}$ candidate at the Department of Political Science and Public Administration at Bilkent University, Turkey. Her research interests are Citizenship, Comparative Citizenship and Policy Changes, Comparative Politics (Comparative Politics of Canada, Germany, Turkey), and Europeanization-Migration-Irregular Migration. Currently, she is working on her thesis titled "Migrants and Citizenship: Turkish Migrants in Canada and Germany."

\section{Bibliography}

“Amount of Fees for Work Permits 2013." Official Gazette no. 28515, 1 January 2013. Accessed August 29, 2013. http://www.csgb.gov.tr/csgbPortal/yabancilar.portal?page=harc_banka

Arı, F. Aylan. Türkiye'de Yabancı İşçiler: Uluslararası Göç, İşgücü ve Nüfus Hareketleri. Istanbul: Derin, 2007.

Aybay, Rona, and Esra Dardağan Kibar. Yabancılar Hukuku. İstanbul: İstanbul Bilgi Üniversitesi, 2010.

BMMYK Türkiye, and Türk İçişleri Bakanlığı. İltica ve Göç Mevzuatı. Ankara: Başkent, 2005.

Brewer, Kelly T., and Deniz Yükseker. "A Survey on African Migrants and Asylum Seekers in Istanbul." MİReKoc Research Projects, 2005-2006.

Çiçekli, Bülent. "Yasadışı Göç,İnsan Kaçakçılığı ve İnsan Ticareti ile Mücadele ve Türkiye." Polis Bilimleri Dergisi 7, no. 1 (2005): 43-57.

Dedeoğlu, Saniye. "Garment Ateliers and Women Workers in Istanbul: Wives, Daughters and Azerbaijani Immigrants." Middle Eastern Studies 47, no. 4 (2011): 663-674.

Directorate General of Migration Managemento, "General Ground of the Law on Foreigners and International Protection”. Accessed September 10, 2013. http://www.goc.gov.tr/default_B0.aspx? content $=1036$

Ekşi, Nuray. Yabancılar ve Uluslararası Koruma Kanunu (Tasarısı). İstanbul: Beta, 2012.

Epstein, Gil S., and Avi Weiss. "The why, when, and how of Immigration Amnesties." Journal of Population Economics 24, no. 1 (2011): 285-316.

Erdem, Esra. "Migrations from the 'Global South' and the Informal Economy in Turkey: Laissez Passer, Laissez Faire?” Revista de Economía Mundial, no. 14 (2006): 87-120.

Erder, Sema, and Selmin Kaşka. Irregular Migration and Trafficking in Women: The Case of Turkey. Geneva: International Organization for Migration, 2003.

Etiler, Nilay, and Kuvvet Lordoğlu. "Göçmenlerin Sağlık Sorunları: Ev Hizmetlerinde Bir Alan Araştırması." Accessed September 4, 2012. http://www.sosyalhaklar.net/2010/bildiri/lordoglu.pdf

Gülçür, Leyla, and Pınar İlkkaracan. "The 'Natasha' Experience: Migrant Sex Workers from the Former Soviet Union and Eastern Europe in Turkey." Women's International Forum 25, no. 4 (2002): $421-441$.

İçduygu, Ahmet. Irregular Migration in Turkey. Geneva: International Organization for Migration, 2003. İçduygu, Ahmet. "The Labor Dimensions of Irregular Migration in Turkey." CARIM Research Reports 5. Florence: Robert Schuman Centre for Advance Studies, European University Institute, 2006.

İçduygu, Ahmet. "Türkiye'de Uluslararası Göçün Siyasal Arkaplanı: Küreselleşen Dünyada 'Ulus-Devleti İnşa Etmek ve Korumak."' In Türkiye’ye Uluslararası Göç: Toplumsal koşullar-Bireysel Yaşamlar, edited by Push, Barbara and Tomas Wilkoszewski der. (Çev. Mutlu Çomak-Özbatır), 17-40. İstanbul: Kitap, 2010.

İçduygu, Ahmet, and Şule Toktaş. "How do Smuggling and Trafficking Operate via Irregular Border Crossings in the Middle East? Evidence from Fieldwork in Turkey." International Migration 40, no. 6 (2002): $25-54$. 
Kaşka, Selmin. "The New International Migration and Migrant Women in Turkey: The Case of Moldovan Domestic Workers." MiReKoc Research Projects, 2005-2006.

Kaya, İbrahim. "Legal Aspects of Irregular Migration in Turkey." CARIM Analytic and Synthetic Notes 73, Irregular Migration Series Legal Module. Florence: Robert Schuman Centre for Advance Studies, European University Institute, 2008.

Kirişçi, Kemal. "Turkey: A Country of Transition from Emigration to Immigration." Mediterranean Politics 12, no. 1 (2007): 91-97.

Kirişçi, Kemal. "Managing Irregular Migration in Turkey: A Political-Bureaucratic Perspective." In CARIM Analytic and Synthetic Notes 73, Irregular Migration Series Socio-Political Module. Florence: Robert Schuman Centre for Advance Studies, European University Institute, 2008.

Massey, Douglas S., Joaquin Arango, Graeme Hugo, Ali Kouaouci, Adela Pellegrino, and J. Edward Taylor. "Theories of International Migration: A Review and Appraisal." Population and Development Review 19, no. 3 (1993): 431-466.

Orrenius, Pia M., and Madeline Zavodny. "Do Amnesty Programs Encourage Illegal Immigration?. Evidence from the Immigration Reform and Control Act (IRCA)." Federal Reserve Bank of Atlanta Working Paper, No. 19, pp. 1-20, 2001.

Özçürümez, Saime, and Nazlı Şenses. "Europeanization and Turkey: Studying Irregular Migration Policy." Journal of Balkan and Near Eastern Studies 13, no. 2 (2011): 233-248.

Parla, Ayşe. "Irregular Workers or Ethnic Kin? Post-1990s Labor Migration from Bulgaria to Turkey." International Migration 45, no. 3 (2007): 157-181.

Republic of Turkey, Ministry of Foreign Affairso. "Turkey’s Fight Against Illegal Migration.” Accessed September 10, 2012. http://www.mfa.gov.tr/turkey__s-fight-against-illegal-migration.en.mfa

Staring, Richard. "Scenes from a Fake Marriage: Notes on the Flip-side of Embeddedness." In The New Migration in Europe: Social Constructions and Social Realities, edited by Koser, Khalid and Helma Lutz, 224-241. London: Macmillan, 1998.

Turkish Ministry of Labor and Social Security (MoLSS). "Kayıtdışı İstihdam ve Yabancı Kaçak İşçi İstihdamı." Genel Yayın 116, 2004.

Turkish Ministry of Labor and Social Security (MoLSS). "Hazır Giyim Sektöründe Çalışan İşçilerin (Risk Grubu: Kadın İşçi) Çalışma Koşullarını İyileştirilmesi Programlı Teftişi Sonuç Raporu.” Yayın 52, 2011. http://www.csgb.gov.tr/csgbPortal/ShowProperty/WLP\%20Repository/itkb/dosyalar/yayinlar/ yayinlar2013/2011_52

Yıldız, Gaye B. "Foreign Workers in Turkey, Their Rights and Obligations Regulated in Turkish Labor Law." European Journal of Migration and Law 9, no. 2 (2007): 207-227.

Zeybekoğlu, Emrehan, and Bo Johansson, eds. Migration and Labor in Europe: Views from Turkey and Sweden. Istanbul: Şefik, Murcır and NIWL, 2003. 